The Journal of Animal \& Plant Sciences, 30(3): 2020, Page: 595-602

ISSN (print): 1018-7081; ISSN (online): 2309-8694

\title{
CONTROLLING LAMBS MORTALITY THROUGH EWES' VACCINATION IN THE FARMS OF KUWAIT
}

\author{
H. A. Burezq ${ }^{1}$, F. Khali1 ${ }^{1}$, J. Dashti ${ }^{1}$, A. Essawi ${ }^{2}$, F. Al-Thefeeri ${ }^{2}$, and M. Farouq ${ }^{2}$, \\ ${ }^{1}$ Desert Agriculture and Ecosystems Program (DAEP), Environment and Life Sciences Research Center (ELSRC), \\ Kuwait Institute for Scientific Research, Kuwait (KISR), P.O. Box 24885 Safat, 13109 Kuwait, ${ }^{2}$ Public Authority for \\ Agricultural Affairs and Fish Resources (PAAFR). \\ Corresponding Author's Email: haborizq@kisr.edu.kw
}

\begin{abstract}
A serious problem in the sheep industry of Kuwait is the high mortality rate of newborn lambs especially during the first three weeks of age. The present study was carried out with the objective to improve the existing vaccination protocol of ewes in the farms of Kuwait, to boost ewe's immunity to produce high quality colostrum. The required baseline data of mortality of young lambs were collected by intensive survey work. Survey studies showed that the mortality rate of young lambs ranged between $30-50 \%$ in the sheep farms of Kuwait. Results of field experiment showed that the concentration of Igs of serum and colostrum collected from vaccinated pregnant ewes during pregnancy period was significantly higher $(P<0.05)$ than the rest of the farms where no vaccination was made during pregnancy, and reached $45.79 \pm 0.561 \mathrm{mg} / \mathrm{ml}$ and $65.9 \pm 0.805 \mathrm{mg} / \mathrm{ml}$ in the serum and colostrum, respectively. In addition, the main causes of lambs' mortality were diagnosed as due to the infections by; Clostridia and Pasteurella. From the present study it is concluded that vaccinating ewes during pregnancy period, resulted in significantly higher $(P<0.05)$ secretion of Igs in ewes' blood and colostrum, which resulted into a positive effect on decreasing the mortality rate of young lambs, and is considered very beneficial to livestock-industry-in-Kuwait.
\end{abstract}

Keyword: Sheep, mortality, morbidity, young lambs, colostrum, survey study https://doi.org/10.36899/JAPS.2020.3.0070

Published online March 25, 2020

\section{INTRODUCTION}

One of the serious problems that affect the sheep industry in Kuwait is the high mortality rate of newborn lambs. The mortality rate of young lambs could be as high as 25 to $35 \%$, especially in the first 3 weeks of age, and thus sheep producers suffer from significant economic losses (Public Authority of Agricultural Affairs and Fish Resources (PAAFR), unpublished data). In the present study, a survey work was conducted in nine sheep farms in different areas of Kuwait. The objective of the survey was to investigate the main causes of lambs' mortality to find practical solutions to reduce lamb's mortality. Lambs' mortality could be due to low immune status especially in the first 21 days of age, in addition to infectious conditions like diarrhea (Woldemariam et al., 2014), and pneumonia (Aziz-Ul-Rahman et al., 2016; Wernike et al., 2014).

Lambs are always born with no immunity and the only source of Igs is to get sufficient amount of colostrum from their dams (Vendrig and Fink-Gremmels, 2012; Bjorkman et al., 2003). Colostrum is the first milk formed by the mammary glands during late pregnancy period, and secreted for few hours after lambing. It is considered the only source of immunity because it contains immunoglobulin (Igs). Thus, to increase the survival rate of newborn lambs, young lambs must suckle sufficient quantity of colostrum in the first 24 hours after birth, to get enough immunity until their immune system become activated (Chase et al., 2008; Durham and Stevenson, 1979). Absorption of colostrum usually occurs through the intestinal cells by the neonatal receptor FcRn and endocytosis process using transport vacuoles (Smith and Foster, 2007; Hasoksuz et al., 2002). This absorptive capacity starts to decrease 6 to 12 hours after birth and ends by 48 hours after birth (Sangild, 2003; Smith and Foster, 2007). The concentration of Igs in lambs' serum increases significantly shortly after colostrum ingestion. Lambs should get sufficient amount of high quality colostrum between 1-6 hours of birth, because the gut ability to absorb the Igs decreases significantly after this period. The amount of colostrum needed per lamb is about $100-200 \mathrm{ml}$ per feeding, which is about $600 \mathrm{ml}$ for 3 times feeding in the first 12 hours of lives, and in case the lambs cannot suckle the colostrum directly from the teat, colostrum should be collected and fed to them by a stomach tube (Nowak and Poindron, 2006). To improve the quality of secreted colostrum, a study was conducted on a small scale at Kuwait Institute for Scientific Research by vaccinating Naeemi ewes during pregnancy against certain diseases such as; Clostridia and Pasteurella. The results showed that a significant $(P<0.01)$ increase in the concentration of Igs in ewes' serum was observed, and this increase started to drop sharply after lambing, and then started to 
rise again during the next four weeks to reach normal level (Burezq et al., 2016; Movsesijan et al., 1975; Nowak and Poindron, 2006). In small ruminants, colostrum IgG accounted for more than 70 to $85 \%$ of the total immunoglobulins. The elevation of $\operatorname{IgG}$ could be related to the fact that this IgG subset was selectively transported to the colostrum before secretion of ruminants, and $\mathrm{Fc}$ portion of $\mathrm{IgG}$ is involved in this transport (Micusan and Borduas, 1975; Rodinova et al., 2008). Sometimes, lambs failed to get sufficient amount of colostrum during the first three days of lives; hence, lambs become more susceptible to diseases and even death.

The total number of sheep in Kuwait is $\approx 588,618$ heads, and the lambs' meat could meet $11-12$ $\%$ of the total red meet demand of Kuwait. Decreasing the mortality rate of lambs could have a positive effect on the sheep industry in Kuwait (Burezq et al., 2016). The above background reviews indicated that a research gap in the immunization protocol was existing in the specialized area of lamb immunity, which is investigated during this study.

\section{MATERIALS AND METHODS}

Survey Work. A survey work was carried out to collect baseline data on lambs' mortality during the first three weeks after birth. The survey was conducted in nine sheep farms in Kuwait. In this survey only Naeemi sheep were considered because it is well-adapted to the local harsh climate; nutritional stress, endemic diseases, and they produce excellent quality of lean meat. During the survey, the selected farms were divided into three categories according to the sizes of the herd found in the farm, 1. Small farms (that is farms having a flock of about $10-150$ heads). 2. Medium farms (that is a farm having a flock of about flock size 151 - 750 heads). 3 . Large farms (that is a farm having a flock of about flock size 751-1000 heads). The survey work was carried out during the main sheep breeding and lamb production season, which usually occurs in autumn (October to November), with planned lambing time (March to April).

Animals. Naeemi Ewes, 1 to 2 years of age and average live weight $38 \pm 2.89 \mathrm{~kg}$, were used in the present study.

Feed and Nutrition. Two different Concentrates (C): Roughages (R) ratios were used. Ration with (70C:30R) was used for ewes and rams, while for young lambs, ration with (80C:20R), was used, as per KISR's feeding and nutritional previous study (Abbas et al., 2015). Rams were provided with $1.0 \mathrm{~kg}$ per head per day. Two weeks before joining ewes, this amount was increased to $1.25 \mathrm{~kg}$ per head per day. Dry ewes were offered $0.8 \mathrm{~kg}$ per head per day of the same feed given to the rams. This amount was gradually increased to $1.25 \mathrm{~kg}$ per head per day during the last month of pregnancy (NRC, $2001 \& 2007$ ), and the KISR's previous study (Abbas et al., 2015). The chosen farms were under the supervision of PAAFR, thus all farms were using the aforementioned rations for ewes, rams and young lambs.

Experimental Design of Field Experiment. A flock of 30 ewes were separated from each farm. Total number of ewes in the present study is $(30$ ewes/farm $\mathrm{X} 9$ farms= 270 ewes). Ewes were ear tagged to monitor their performance. Selected flocks were vaccinated according to the vaccination protocol used originally in the farm. Body Condition Score (BCS) of selected ewes was $3.0-$ 3.5 to insure ewes would successfully feed their lambs. After that a straight breeding program of mating Naeemi rams X Naeemi ewes was used (Razzaque, 1995). Blood samples were collected before and after vaccination, while colostrum samples were collected after lambing to measure the total Igs using ELISA technique.

Proximate Analysis. The analysis of crude protein in feed samples was carried out using Kjeldahl Method (AOAC, 2012), while the crude fat was measured using the Soxlet Apparatus (BUCHI, Switzerland) (AOAC, 2012). Moisture (\%) was determined according to the method mentioned previously 9.1.6.1. (ISTA, 2007), and the Ash content was determined according to the method number 923.03 (AOAC, 2012).

Vaccination Protocol. Ewes were vaccinated according to the vaccination protocol recommended by PAAFR or KISR depending on the selected farm. Thus, ewes from 8 out of 9 farms (under the supervision of PAAFR) were vaccinated with 1. Clostridial vaccine, which consists of seven species of the antigen including, Cl. Septicum; $\mathrm{Cl}$. Perfringens Types $\mathrm{A}, \mathrm{C}$, and $\mathrm{D} ; \mathrm{Cl}$. Sordellii; and $\mathrm{Cl}$. novy, Type $B$ toxoids (CZ Veterinaria S. A, Spain). 2. Pasteurella vaccine. (CZ Veterinaria S. A, Spain), before pregnancy period, and no intervention measures were taken during pregnancy period, while KISR's vaccination protocol (KISR farm) was strictly used by vaccinating ewes during pregnancy period twice, $1^{\text {st }}$ vaccination was at the beginning of the pregnancy period, and the $2^{\text {nd }}$ booster dose was given four weeks prior to lambing.

Collection of Blood and Colostrum Samples. Blood samples were collected before the morning feeding from the jugular vein in 10-ml vacutainer tubes as per the procedure described by Stevanović et al., (2015). Colostrum was collected in clean plastic screw-top containers and stored at $-20^{\circ} \mathrm{C}$. The concentration of Igs in the colostrum and serum samples were determined by Enzyme-Linked Immunosorbent Assay (ELISA) kits (SunLong, China), and the results were expressed in $\mathrm{mg} / \mathrm{ml}$ of serum or colostrum (Crowther, 2000; Dogra et al., 2015). Total number of collected blood samples was 1350; blood samples were collected before and after $1^{\text {st }}$ and $2^{\text {nd }}$ vaccinations, and after lambing. The total number 
of collected colostrum samples was 270 samples ( 2 hours after lambing).

Diagnosis of Diseases that Causes Lambs' Mortality. To diagnose the causes of lamb's mortality, tissues were collected from different organs of dead lambs, using Koch's Postulates (Prescotta et al., 2017). Koch postulated depends mainly on 3 rules: 1 - The isolated microorganism should be isolated from all animals infected with the same disease. 2- The microorganism should be isolated from the infected animal and grown in pure culture. 3- This specific microorganism should be reproduced when inoculated into a healthy animal.

\section{RESULTS}

Data Collected From Survey Work. The survey work showed that the mortality rate of young lambs ranged between $30-50 \%$ in sheep farms of Kuwait.

As stated above a field experiment was carried out to study the main causes of high mortality rate in sheep farms, therefore, blood and colostrum samples were collected to measure the concentration of Igs.

Igs Concentration of Blood Serum. The concentration of Igs in collected blood samples from pregnant ewes ranged between $18.34 \pm 0.67 \mathrm{mg} / \mathrm{ml}$ to $23.31 \pm 0.96 \mathrm{mg} / \mathrm{ml}$, in eight farms. In contrast, it was significantly higher $(P<0.05)$ in KISR farm $(45.79 \pm 0.56 \mathrm{mg} / \mathrm{ml})$, as compared to the rest of the farms (Table 1). The concentration of Igs in serum samples collected from KISR farm (where the ewes were vaccinated twice during pregnancy), was significantly $(P<0.05)$ higher than the concentration of Igs in serum samples collected from other farms (where no intervention measures were taken during pregnancy period). The significant difference is due to the vaccination of ewes during pregnancy that has improved the immune status of ewes, due to higher Igs production. These results are in close agreement with the results of Gilbert et al. (2014) and Hashemi et al., (2008), who have also reported increased Igs after vaccinating ewes during pregnancy, which has resulted in the improvement of ewes' immunity.

Igs Concentration of Colostrum. Table 2 shows that the concentration of Igs in colostrum samples from eight farms ranged between $50.43 \pm 0.53 \mathrm{mg} / \mathrm{ml}$ and $53.06 \pm 0.95$ $\mathrm{mg} / \mathrm{ml}$. The concentration of Igs in colostrum samples collected from KISRs' farm was significantly higher $(P<0.05) 65.96 \pm 0.81 \mathrm{mg} / \mathrm{ml}$ than the rest of the farms. These results showed that, vaccinating ewes during pregnancy period managed to increase significantly $(P<0.05)$ the concentration of Igs in the colostrum, that could positively affect the survival rate of the newborn lambs. Thus, improving the immunity of ewes by vaccinating them twice during pregnancy period, would help in elevating Igs concentration in their blood and consequently in the secreted colostrum. Having high concentration of Igs in colostrum, would help in improving the immune status of lambs feeding on the colostrum, as a result lambs would have enough immunity especially in the first 3 weeks of age, until their immune system becomes fully activated. It is, therefore, essential to increase the quality of the colostrum to increase the survival rate of newborn lamb because colostrum is the only source of antibodies (MartínGómez et al., 2006).

Table 1. Concentration of IgG in ewes' blood serum.

\begin{tabular}{ccccc}
\hline Farms & \multicolumn{4}{c}{$\boldsymbol{I g G} \boldsymbol{~} \boldsymbol{g} / \boldsymbol{m} \boldsymbol{l}$} \\
& ${ }^{* * *} \boldsymbol{F}-\mathbf{1}$ & $\boldsymbol{F}-\mathbf{2}$ & $\boldsymbol{F}-3$ & Mean $\pm \boldsymbol{S D}$ \\
\hline 1 & 19.96 & 20.20 & 17.86 & $19.34 \pm 1.29$ \\
2 & 20.48 & 30.39 & 19.06 & $23.31 \pm 0.96$ \\
3 & 19.12 & 18.03 & 17.88 & $18.34 \pm 0.67$ \\
4 & 20.79 & 19.96 & 20.56 & $20.43 \pm 0.43$ \\
5 & 19.80 & 19.16 & 18.05 & $19.01 \pm 0.89$ \\
KISRs' & 46.14 & 45.14 & 46.08 & $45.79 \pm 0.56$ \\
Farm & & & & \\
6 & 20.73 & 19.83 & 21.72 & $20.76 \pm 0.95$ \\
7 & 19.50 & 20.61 & 21.75 & $20.62 \pm 0.60$ \\
8 & 19.99 & 19.10 & 18.41 & $19.17 \pm 0.80$ \\
\hline
\end{tabular}

${ }^{*}:$ F1: Flock-1, ${ }^{* *}$ These values express the mean value of Igs concentration in blood serum collected from all ewes in flock-1, after the $2^{\text {nd }}$ vaccination, $n=10$ for each flock.

Table 2. Concentrations of IgG in colostrum samples

\begin{tabular}{ccccc}
\hline \multicolumn{5}{c}{$\boldsymbol{I g G} \boldsymbol{m g} / \boldsymbol{m l}$} \\
Farms & ${ }^{*, * *} \boldsymbol{F}-\mathbf{1}$ & $\boldsymbol{F - 2}$ & $\boldsymbol{F - 3}$ & Mean $\pm \boldsymbol{S D}$ \\
\hline 1 & 51.45 & 52.53 & 51.88 & $51.95 \pm 0.54$ \\
2 & 53.01 & 54.04 & 52.14 & $53.06 \pm 0.95$ \\
3 & 50.54 & 52.07 & 51.77 & $51.46 \pm 0.81$ \\
4 & 52.11 & 51.21 & 50.33 & $51.22 \pm 0.89$ \\
5 & 50.09 & 50.23 & 51.33 & $50.55 \pm 0.69$ \\
KISRs, & 65.15 & 66.76 & 65.97 & $65.96 \pm 0.81$ \\
Farm & & & & \\
6 & 49.85 & 50.88 & 50.57 & $50.43 \pm 0.53$ \\
7 & 50.30 & 51.13 & 50.20 & $50.54 \pm 0.09$ \\
8 & 50.33 & 50.98 & 51.06 & $50.79 \pm 0.42$ \\
\hline${ }^{*}:$ F1: Flock-1, ${ }^{* *}$ These values express the mean value of Igs \\
concentration in colostrum samples collected from all ewes in \\
flock-1 after lambing, n= 10 for each flock.
\end{tabular}

Mortality Rate of Newborn Lambs (MR). Table 3 shows that the mortality rate (MR) of young lambs in KISRs' farm was significantly $(P<0.05)$ lower than the rest of the farms. The MR of lambs in the rest of the farms ranged between $20.11 \%-30.56 \%$ during the field experiment, especially in the first 3 weeks of age. During the field experiment, all the parameters were unified including; feed, BSC, and management. The only difference between these farms and KISRs' farm is the 
vaccination protocol used, in order to investigate the effect of using different vaccination protocols on lambs' mortality. Thus, these results showed that vaccinating ewes during pregnancy period, could help in boosting the immunity of ewes during pregnancy, and as a result improve the quality of secreted colostrum. In addition, lambs feeding on high quality colostrum helped these lambs to have more chances for survival, since colostrum is the only source for antibodies and nutrition for newborn lambs. Thus, improving the quality of colostrum, would help in boosting the immunity of young lambs and reducing lambs' mortality rate.

Diseases Causing Lambs' Mortality. Biological samples were collected from dead lambs, and were sent to PAAFR laboratories for diagnosis. The results showed that the mortality of lambs at the first 3 week of age, were usually due to their infection with some pathogens such as; enterotoxigenic Escherichia coli from enteric or septicemic forms, Clostridia, Pasteurella, FMD, Salmonella, PPR, and Coronavirus and Rotavirus. Infected lambs with the above-mentioned pathogens exhibited some symptoms such as; fever, diarrhea, poor appetite, weight loss due to sores in mouth (Scholes and Edwards, 2009; Khan et al., 2018; Durham and Stevenson, 1979).

Abortion Rate of Ewes. Table 4 shows that the abortion rates of ewes in eight farms were ranged between 3.33 $9.52 \%$. The abortion rate in KISRs' farm was significantly $(P<0.05)$ the lowest, as compared to the other farms and reaches $0 \%$. The abortion of ewes occurs as a result of infections with some diseases during pregnancy period, for example; Campylobacter fetus subsp., fetus fibrosis, Campylobacter jejuni, Chlamydophila abortus (enzootic abortion of ewes); Lister monocytogenes (listeriosis), Salmonella abortusovis, Brucella melitensis, Toxoplasma gondii (Toxoplasmosis), bluetongue virus and border disease (Mohale, 2013). Biological samples were taken from dead fetus and send to laboratory to diagnose the causes of the abortion. The results showed that the abortion of ewes (Figure 1) was due to the infection of; Brucella melitensis (50\%), Toxoplasma gondii (Toxoplasmosis) (30\%), Chlamydophila abortus (7\%), Campylobacter fetus sub-sp. (5\%), C. fetus fibrosis (2\%), Lister monocytogenes (listeriosis) (2\%), and Salmonella abortus-ovis (2\%), as shown in Figures 1. The results showed that the vaccination protocol used for vaccinating pregnanct ewes in KISR's farm was very effective, it takes care of ewes during pregnacy period by boosting their immunity, thus there was no abortion cases recorded during the field experiment.

Table 3. Mortality of young-lambs at 1-21 days of age

\begin{tabular}{cc}
\hline Farms & Mortality-Rate \\
\hline 1 & 22.22 \\
2 & 22.22 \\
3 & 30.56 \\
4 & 22.22 \\
5 & 22.22 \\
KISRs' Farm & 0 \\
6 & 30.56 \\
7 & 20.11 \\
8 & 30.56 \\
\hline
\end{tabular}

Table 4. Abortion rate (\%) of ewes.

\begin{tabular}{cc}
\hline Farms & Abortion (\%) \\
\hline 1 & 9.52 \\
2 & 9.52 \\
3 & 9.52 \\
4 & 4.76 \\
5 & 9.52 \\
KISRs' Fram & 0 \\
6 & 9.52 \\
7 & 3.33 \\
8 & 9.52 \\
\hline
\end{tabular}

\section{Causes of Abortion to Pregnant Ewes}

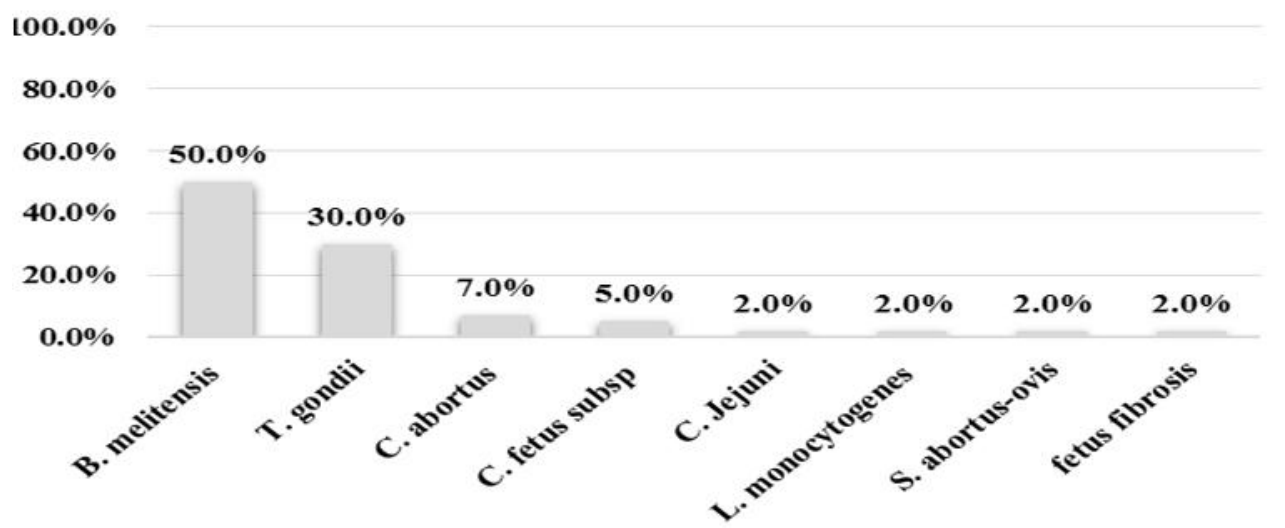

Figure 1. Causes of Abortion of Pregnant Ewes. 
Proximate Analysis of Experimental Rations. During the field experiment, many factors were unified such as; management level, ration used, body condition score and age of ewes. Unifying these factors will help in evaluating the efficiency of vaccination protocol used in the selected farms, especially on the mortality of young lambs. The composition of the experimental rations based on $\mathrm{C}$ and $\mathrm{R}$ ration is shown in Table 5. In the present study, two different $\mathrm{R}$ and $\mathrm{C}$ ratios were used. The ration used for ewes and rams was (70C:30R), it was reported to be the best feeding regime used so far in KISRs' farm for complete production cycle of ewes, in Kuwait's feedlot system irrespective of the season (Abbas et al., 2015). The ration with (80C:20R), used for lambs was reported to be the best for lambs during the pre-weaning, suckling and post-weaning periods, and for the best Average Daily Gain (ADG) and Feed Conversion Ratio (FCR) for lambs (Abbas et al., 2015).

Table 5. Composition of Experimental Rations (Combined Concentrates and Roughages).

\begin{tabular}{lcc}
\hline & \multicolumn{2}{c}{ Composition of Rations } \\
\hline *Component & $\begin{array}{c}\text { (70C: } 30 R) \\
\text { (For } \text { ewes } \text { and } \\
\text { rams) }\end{array}$ & $\begin{array}{c}\text { (80C: } 20 R \text { ) } \\
\text { (For young lambs) }\end{array}$ \\
\hline Moisture & $8.03 \pm 0.13$ & $9.37 \pm 0.24$ \\
$\mathrm{DM}$ & $90.98 \pm 0.1$ & $90.64 \pm 0.25$ \\
Ash $^{*}$ & $5.48 \pm 0.18$ & $2.64 \pm 0.07$ \\
$\mathrm{CP}^{*}$ & $13.32 \pm 0.29$ & $12.45 \pm 0.12$ \\
$\mathrm{EE}^{*}$ & $1.56 \pm 0.84$ & $2.85 \pm 01.61$ \\
$\mathrm{NDF}$ & $20.11 \pm 0.56$ & $19.86 \pm 0.30$ \\
$\mathrm{ADF}$ & $4.95 \pm 0.28$ & $4.55 \pm 0.45$ \\
$\mathrm{Ca}^{*}$ & $0.37 \pm 0.051$ & $0.43 \pm 0.20$ \\
$\mathrm{P}^{*}$ & $1.26 \pm 0.04$ & - \\
\hline${ }^{*} \mathrm{DM}: \%$
\end{tabular}

${ }^{*}$ DM: \% of Dry matter; CP: Crude Protein; EE: Ether Extract; ADF: Acid Detergent Fiber; NDF: Neutral Detergent Fiber; Ca: Calcium; P: Phosphorous; -: not available: DM: Dry Matter.

\section{DISCUSSION}

In the present study, the concentration of Igs was increased significantly $(P<0.05)$ during the gestation period due to vaccination of ewes. Ewes were vaccinated twice with Clostridia and Pasteurella vaccines, during pregnancy. Igs concentration was increased by $22.48-$ $28.38 \mathrm{mg} / \mathrm{ml}$ (KISR' farm), over the Igs level in blood samples collected from other farms (Table 1). It is observed that the elevation in antibody titer started from the $8^{\text {th }}$ week before parturition, until it reached the normal concentration at parturition, and then started to rise again during the next four weeks after parturition. These findings agree with what was published previously by Saucedo et al., (2011), Vatankhah (2013) and Movsesijan et al., (1975), who have reported that, a significant elevation was observed in serum $\operatorname{IgG}$ concentration after vaccinating sheep against Fasciola hepatica (Jovanovic 1975).

The concentration of Igs in colostrum samples collected from vaccinated ewes was increased by 19 $24 \%$, as compared to colostrum samples collected from the other farms (Table 2). This observation could be interpretated as, the secreted antibodies in ewes' serum, were transferred into the colostrum by selective receptormediated intracellular route (Kacskovics, 2004). Fc is the specific receptor for transferring IgG antibody from the serum to mammary gland, and it is regulated by hormonal changes during the pregnancy period (Yilmaz et al., 2011; Tabatabaei et al., 2013). There are many functions of $\mathrm{Fc}$ receptor such as; $\operatorname{IgG}$ metabolism, and prevention of the degradation of IgG in maternal circulation. It also plays an important role in determining the concentration of IgG in the colostrum (Brujeni et al., 2010; Kacskovics, 2004; Baintner, 2007; Lerias et al., 2014). The expression of FcRn receptor increased in dry ewes, during late gestation period, and decreased during colostrogenesis (i.e., transfer of Igs from ewes' blood circulation into the colostrum, which occurs in the last two weeks before parturition and lactation period) (Hine et al., 2010; Hernandez-Castellano et al., 2014; Brujeni et al., 2010, Rudovsky et al., 2008; Weaver et al., 2000), and Fc portion of $\mathrm{IgG}$ is involved in this transport (Micusan and Borduas, 1975). It is concluded here that vaccinating ewes during pregnancy period is very efficient, it helped in boosting Igs production significantly $(P<0.05)$ in the blood and helped in the production of high quality colostrum. In the present study, IgG was measured in both serum and colostrum samples, but there are two other classes of Igs that are usually synthesized during the last few weeks of pregnancy by the plasma cells, which are located in the sub-mucosa of the mammary gland epithelium (i.e. IgM, and $\operatorname{Ig} \mathrm{A}$ ) (Yilmaz and Kasikci, 2013). In small ruminant's colostrum, IgG accounted for more than 70 to $85 \%$ of the total Igs in the body. The mechanism of the selective transport of Igs classes from blood into colostrum still needs to be investigated elsewhere and in Kuwait. However, an initiative was taken in this study to explore the transfer of other classes of Igs to ewes' colostrum. The preliminary results revealed that, the insignificant elevation of $\operatorname{IgA}$ in colostrum samples ranged between $9.773 \pm 1.01 \mathrm{mg} / \mathrm{ml}$ and $10.01 \pm 0.74 \mathrm{mg} / \mathrm{ml}$, as compare with colostrum samples collected from unvaccinated ewes $(8.145 \pm 1.44)$. Furthermore, the in significant elevation of $\operatorname{IgM}$ in colostrum samples ranged between $5.575 \pm 1.3 \mathrm{mg} / \mathrm{ml}$ and $6.676 \mathrm{mg} / \mathrm{ml}$, as compare with colostrum samples collected from unvaccinated ewes $(3.52 \pm 0.12 \mathrm{mg} / \mathrm{ml})$, these are initial results which needs further investigation for solid conclusion in this regards.

There are some factors that affect the amount of colostrum secreted such as; the high concentration of plasma progesterone, which was found to have a negative 
effect on the amount of colostrum secreted. Furthermore, in case of poor nutritional status of ewes during pregnancy period, this nutritional status could negatively affect the colostrum yield, and consequently the lambs' survival (Nowak and Poindron, 2006). After parturition, the concentration of antibodies in the colostrum was observed to decrease with time (Baintner, 2007), and the highest IgG concentration in serum was noticed to be during the late pregnancy period and at the first hours after parturition (Hine et al. 2010), and then a rapid decrease was observed at 12 and 24 hours post-partum (Hashemi et al., 2008). It was observed that the concentration of IgG in ewes' serum was correlated with IgG concentration in colostrum, these results are supported by Hashemi et al., (2008), who had reported that there is a positive correlation between the elevation of Igs in blood serum and Igs level in secreted colostrum. In addition, there is another factor that affects the concentration of colostral $\mathrm{IgG}$, in which is the age of ewes. Adult ewes could produce more colostrum with higher concentration of $\mathrm{IgG}$ than younger animals (Yilmaz and Kasikci, 2013), this finding supported our results because ewes in the present study were middleaged animals. Also, another important factor is the ewes' udder condition. Mastitis in ewes was reported to reduce serum Igs in ewes and consequently, in the colostrum (Chirstley et al., 2003; Lascelles, 1979); ewes in the present study were free of mastitis. In addition, ewes fed on $60 \%$ NRC requirement were reported to have a higher average of $127.7 \mathrm{mg} / \mathrm{ml} \mathrm{IgG} \mathrm{in} \mathrm{colostrum.} \mathrm{This} \mathrm{value} \mathrm{was}$ decreased to $99.0 \%$ when ewes were fed at $140 \%$ above the requirements of NRC (2007) (Swanson et al., 2008), this finding supported our results because ewes in the present study were fed on per NRC (2007) recommendation rations. Length of gestation period is another important factor that could affect the composition of colostrum. Ewes with a gestation period of 146 day were reported to have low colostral IgG content, as compared to animals with longer gestation length. Ewes having long gestation period up to 150 day could produce colostral IgG with high concentration reaching 127.7 $\mathrm{mg} / \mathrm{ml}$, as compared to animals with shorter gestation period of 146.5 day with $99.9 \mathrm{mg} / \mathrm{ml}$ (Castro et al., 2011). These results support our finding, because ewes in the present study have gestation length of 149 to 150 day, and a significant $(P<0.05)$ elevation of Igs' concentration was observed in collected colostrum samples.

Conclusions: The survey study showed that the mortality rate of young lambs in Kuwait is very high, and could be as high as $30-50 \%$ in sheep farms.

- The concentration of Igs of serum of ewes after $2^{\text {nd }}$ vaccination and colostrum after lambing, were significantly higher $(P<0.05)$, as compared to other farms, and reached $45.79 \pm 0.56 \mathrm{mg} / \mathrm{ml}$ and $65.96 \pm 0.81$ $\mathrm{mg} / \mathrm{ml}$, respectively.
- The mortality rate of lamb's ranged between 20.11-30.56\%, in sheep farms, while there was no incidence of lamb' mortality in KISRs' farm.

- The main causes of lambs' mortality in sheep farms of Kuwait was the infection with some diseases such as; Clostridia, Pasteurella, Coronavirus, and Rotavirus.

- $\quad 50 \%$ of ewes' abortion was caused due to the infection with $B$. melitensis, while $T$. gondii was responsible for $30 \%$ of ewes' abortion.

Acknowledgements: The project team members wish to express their appreciation to the managements of Kuwait Foundation for the Advancement of Sciences (KFAS), and Kuwait Institute for Scientific Research (KISR) for funding the study. The appreciation is also extended to Public Authority of Agricultural Affairs and Fish Resources (PAAFR) for cooperation and In-kind contribution. Special thanks are extended to Dr. Abdul Rahman Al-Kanderi, Dr. Yousif Al-Shereeda, Ms. Maha Al-batel, and Mr. Khalid Al-Mutawa'a for their help in the laboratory and fieldwork.

Conflict of Interest: The authors declare that there is no conflict of interest.

\section{REFERENCES}

Abbas, S., M. A. Razzaque, A. Elsaid, S. Albert, A. Gelan, F. Khalil, M. Al-Bahouh, A. Naseeb, and H. Burezq. (2015). The effect of nutrition and season of breeding on reproductive performance of Naeemi ewes. Final Research Report, KISR NO. 12848, Kuwait Institute for Scientific Research.

Association of Official Agricultural Chemists (AOAC). (2012). Official Method of Analysis, 19 $9^{\text {th }}$ Ed., Washington DC, pp. $1-350$.

Aziz-Ul-Rahman, M. Abubakar, M. H. Rasool, S. Manzoor, M. Saqalein, M. Rizwan, M. Munir, Q. Ali, and J. J. Wensman. (2016). Evaluation of risk factors for Peste des Petits ruminants virus in sheep and goats at the Wildlife-Livestock Interface in Punjab province Pakistan, pp. 1-6.

Baintner, K. (2007). Transmission of antibodies from mother to young: Evolutionary strategies in a proteolytic environment. Veterinary Immunology and Immunopathology. 117:153161.

Bjorkman, C., C. Svensson, B. Christensson, and K. deVerdier. (2003). Cryptosporidium parvum and Giardia intestinalis in calf diarrhoea in Sweden. Acta Veterinaria Scandinavica. 44 (3-4):145152.

Brujeni, G. N., S. S. Jani, N. Alidadi, S. Tabatabaei. H. Sharifi, and M. Mohri. (2010). Passive immune 
transfer in fattailed sheep: evaluation with different methods. Small Ruminant Research. 90:146-149.

Burezq, H., F. Khalil, M. Razzaque, S. Albert, S. Ali, Z. Al-Ballam, and W. Al-Qalaf. (2016). Biochemical and humoral evaluations of normal colostrum and hyperimmune colostrum of sheep and goats. Final Research Report for Project FA118K, Kuwait Institute for Scientific Research. KISR NO. 13466.

Castro, N., J. Capote, R. M. Bruckmaier, and A. Arguello. (2011). Management effect on colostrogenesis in small ruminants: a review. Journal of Applied Animal Research. 39:85-93.

Chase, C., D. Hurley, and A. Reber. (2008). Neonatal immune development in the calf and its impact on vaccine response. Veterinary Clinics of North America-Food Animal Practice. 24(1):87-104.

Chirstley, R. M., K. L. Morgan, T. D. H. Parkin, and N. P. French. (2003). Factors related to the risk of neonatal mortality, birth-weight and serum immunoglobulin concentration in lambs in the UK. Preventive Veterinary Medicine. 57:209226.

Crowther, J. R. (2000). The ELISA Guidebook. $2^{\text {nd }}$ Ed. Totowa (NJ): Humana Press. Pp. 9-44.

Dogra, V., S. Verma, G. Singh, A. H. Wani, R. Chahota, P. Dhar, L. Verma, and M. Sharma. (2015). Development of OMP based indirect ELISA to gauge the antibody titers in bovines against Pasteurella multocida. The Iranian Journal of Veterinary Research. 16(4):350 -356.

Durham, P. J., and B. J. Stevenson. (1979). Rotavirus and coronavirus associated diarrhea in domestic animals. New Zealand Veterinary Journal. 27(3):30-32.

Gilbert, R. P., C. T. Gaskins, J. K. Hillers, C. F. Parker, and T. C. McGuire. (2014). Genetic and environmental factors affecting immunoglobulin $\mathrm{G}$ concentrations in ewes' colostrum and lambs serum. Journal of Animal Sciences. 66(4):855863.

Hashemi, M., M. J. Zamiri, and M. Safdarian. (2008). Effects of nutritional level during late pregnancy on colostral production and blood immunoglobulin levels of Karakul ewes and their lambs. Small Ruminant Research. 75(23):204 - 209.

Hasoksuz, M., A. E. Hoet, S. C. Loerch, T. E. Wittum, P. R. Nielsen, and L. J. Saif. (2002). Detection of respiratory and enteric shedding of bovine coronaviruses in cattle in an Ohio feedlot. Journal of Veterinary Diagnostic Investigation. 14(4):308-313.

Hernandez-Castellano, L. E., A. M. Almeida, N. Castro, and A. Argüello. (2014). The colostrum proteome, ruminant nutrition and immunity: A review. Current Protein and Peptid Science $15: 64-74$

Hine, B. C., P. W. Hunt, A. M. Beasley, R. G. Windon, S. A. Glover, and I. G. Colditz. (2010). Selective transport of IgE into ovine mammary secretions. Research in Veterinary Science. 89:184-190.

ISTA. (2007). International rules for seed testing, Rules. Zurich, Switzerland: International Seed Testing Association.

Jovanović. M. M. (1975). Immune response of sheep to Fasciola hepatica infection. Research Veterinary Science. 18:171-174.

Kacskovics, I. (2004). Fc receptors in livestock species. Veterinary Immunology and Immunopathology. 102:351-362.

Khan, A., M. K. Saleemi, F. Ali, M. Abubakar, R. Hussain, R. Z. Abbas, and I. A. Khan. (2018). Pathophysiology of Peste des Petits ruminants in sheep (Dorper \& Kajli) and goats (Boer \& Beetal). Microbial Pathogenesis. 117:139 - 147.

Lascelles, A. K. (1979). Immune system of the ruminant mammary gland and its role in the control of mastitis. Journal of Dairy Science. 62:154-167.

Lerias, J. R., L. E. Hernandez-Castellano, A. SuarezTrujillo, N. Castro, A. Pourlis, and A. M. Almeida. (2014). The mammary gland in small ruminants: Major morphological and functional events underlying milk production-A review. Journal of Dairy Research. 81:304-318.

Martín-Gómez, S., M. A. Alvarez-Sánchez, and F. A. Rojo-Vázquez. (2006). Obtaining hyperimmune anti-cryptosporidium parvum ovine colostrum. A study of the humoral immune response in immunized sheep. Parasitology Research. 98:129.

Micusan, V. V., and A. G. Borduas. (1975). Preferential transport into colostrum of $\mathrm{Fc}$ fragment derived from serum IgG1 immunoglobulin in the goat. Research Veterinary Science. 24:150.

Mohale, D. (2013). Abortions and causes of death in newborn sheep and goats. Published by Department of Agriculture, Forestry \& Fisheries. Republic of South Africa. https://www.nda.agric.za/docs/Infopaks/abort.pd f (Accessed October 27, 2013)

Movsesijan, M., V. Hirstic, L. Bezbradica, B. Javovich, A. Pavlovich, Z. Radojkovicz, V. Tomic, and P. Nicolic. (1975). Absorption of immunoglobulin $(\mathrm{IgG})$ in the newborn piglet. Veterinarski glasnik Journal 12:877-883.

Nowak, R., and P. Poindron. (2006). From birth to colostrum: early steps leading to lamb survival. Reproduction Nutrition Development. 46(4):431-446. Presented in a symposium entitled: Influence of nutrition and socio-sexual 
context on reproduction and survival of the young in goats and sheep.

NRC (National Research Council). (2007). Nutrient Requirement of Small Ruminants. The National Academic Press, Washington, DC. www.nap.edu.

NRC (National Research Council). (2001). Nutrient Requirements of Dairy Cattle, $7^{\text {th }}$ ed. Washington, D.C.: National Research Council. National Academy Press.

Prescotta, J., H. Feldmanna, and D. Safronetz. (2017). Amending Koch's postulates for viral disease: when "growth in pure culture" leads to a loss of virulence. Antiviral Res. 137: 1-5.

Razzaque, M. A. (1995). Intensive lamb production using local and imported sheep. Final Research Report, KISR NO. 1763, Kuwait Institute for scientific Research.

Rodinova, H., V. Kroupova, J. Travnicek, M.Stankova, and L. Pisek. (2008). Dynamics of IgG in the blood serum of sheep with different selenium intake. Veterinarni Medicina. 53 (5):260-265.

Rudovsky, A., L. Locher, A. Zeyner, A. Sobiraj, and T. Wittek. (2008). Measurement of immunoglobulin concentration in goat colostrum. Small Ruminant Research. 74:265269.

Sangild, P. T. (2003). Uptake of colostral immunoglobulins by the compromised newborn farm animal. Acta Veterinaria Scandinavica. 98:122.

Saucedo, J. S., E. Avelar, L. Avendano, A. Perez, and M. P. Gallegos. (2011). mmunoglobulin Transference from Maternal Colostrum and Colostrum Substitute in Holstein Calves in Mexicali. Proceedings, Western Section, American Society of Animal Science. 62:145147.

Scholes, S. F., and G. T. Edwards. (2009). Tyzzer's disease (Clostridium piliforme infection) and possible copper toxicity in a lamb. Veterinary Record. 164(15):470-471.

Smith, G. W., and D. M. Foster. (2007). Short communication: Absorption of protein and immunoglobulin $\mathrm{g}$ in calves fed a colostrum replacer. Journal of Dairy Science. 90:2908.

Stevanović, O., M. Stojiljković, D. Nedić, D. Radoja, V. Nikolić, R. Prodanović, S. Ivanov, and I. Vujanac. (2015). Variability of blood serum biochemical parameters in Karakachan sheep.
Biotechnology in Animal Husbandry. 31(1):5562.

Swanson, T. J., C. J. Hammer, J. S. Luther, D. B. Carlson, J. B. Taylor, D. A. Redmer, T. L. Neville, J. J. Reed, L. P. Reynolds, J. S. Caton, and K. A. Vonnahme. (2008). Effects of gestational plane of nutrition and selenium 40 supplementation on mammary development and colostrum quality in pregnant ewe lambs. Journal of Animal Science. 86:2415-2423.

Tabatabaei, S., G. Nikbakht, M. Vatankhah, H. Sharifi, and N. Alidadi. (2013). Variation in colostral immunoglobulin $\mathrm{G}$ concentration in fat tailed sheep and evaluation of methods for estimation of colostral immunoglobulin content. Acta Veterinaria Brno. 82:271-275.

Vatankhah, M. (2013). Relationship between immunoglobulin concentration in the Ewes Serum and Colostrum, and Lambs Serum in Lori-Bakhtiari Sheep. Iranian Journal of Applied Animal Science. 3:539-544.

Vendrig, J. C., and J. Fink-Gremmels. (2012). Intestinal barrier function in neonatal foals: Options for improvement. The Veterinary Journal. 193(1):32-37.

Weaver, D. M., J. M. Tyler, D. C. VanMetre, D. E. Hostetler, and G. M. Barrington. (2000). Passive transfer of colostral immunoglobulins in calves. Journal of Veterinary Internal Medicine. 14:569. 577.

Wernike, K., M. Eschbaumer, A. Breithaupt, J. Maltzan, H. Wiesner, M. Beer, and B. Hoffmann. (2014). Experimental infection of sheep and goats with a recent isolate of Peste des Petits ruminant's virus from Kurdistan. Veterinary Microbiology. 172(1-2):140-145.

Woldemariam, S., S. Zewde, D. Hameto, and A. Habtamu. (2014). Major causes of lamb mortality at Ebinatworeda, Amhara National Regional State, North-Western Ethiopia. Ethiop. Vet. J. 18(1):57-71.

Yilmaz, O. T., G. Kasikci, and M. C. Gunduz. (2011). Benefits of pregnant sheep immunostimulation with Corynebacterium cutis on post-partum and early newborn's life IgG levels, stillbirth rate and lamb's weight. Small Ruminant Research. 97:146-151.

Yilmaz, O., and G. Kasikci. (2013). Factors affecting colostrum quality of ewes and immunostimulation. Turkish Journal of Veterinary and Animal Sciences. 37:390-394. 